\title{
WHAT DO PUBLIC POLICIES TEACH US ABOUT RURAL DEPOPULATION: THE CASE STUDY OF SPAIN
}

\author{
Vicente Pinilla ${ }^{1}$, Luis Antonio Sáez ${ }^{2}$
}

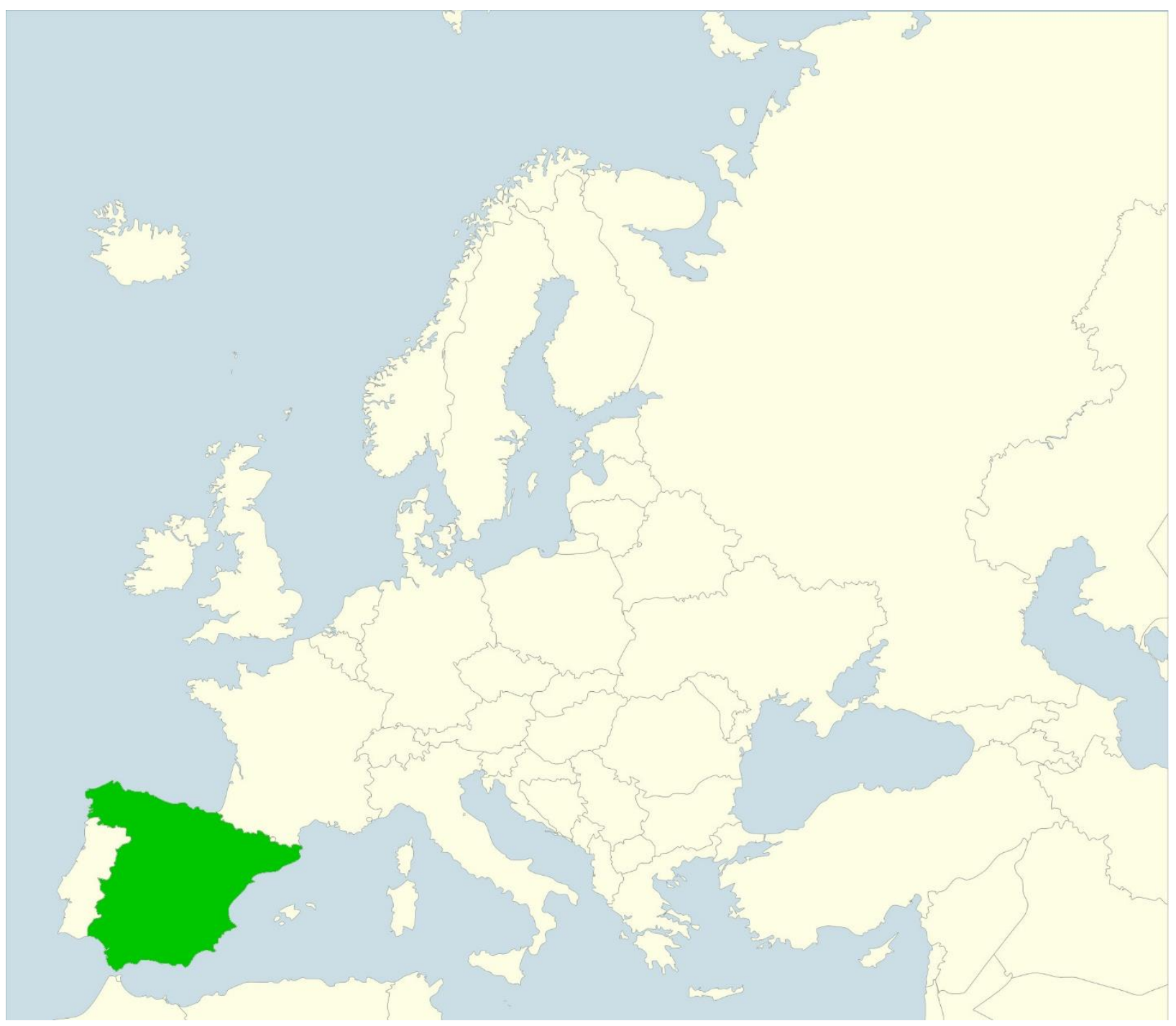

\footnotetext{
${ }^{1}$ Professor Vicente Pinilla, Universidad de Zaragoza, Faculty of Economics and Business Studies, Zaragoza, Spain; e-mail: vpinilla@unizar.es, ORCID: 0000-0003-2256-8898

2 Associated Professor Luis Antonio Sáez Pérez, Universidad de Zaragoza, Faculty of Economics and Business Studies, Zaragoza, Spain; e-mail: lasaez@unizar.es, ORCID: 0000-0002-2228-7861
} 
Abstract: This study evaluates the policies developed in Spain to address depopulation and explains the reasons for their low effectiveness. We consider that the low impact of these policies is due to an incorrect diagnosis and design in terms of their content and governance. Therefore, we propose that depopulation policies should have the objective of enabling citizens to reside where they wish and obtain the best possible quality of life. These policies should be implemented within a new governance framework in which the foundations on which they are based and the way in which they are implemented are renewed. With the support of the European Union, such action could be carried out more efficiently and could constitute a reference of successful territorial cohesion contributing to erasing the populist opinion in places that believe that they do not matter.

Keywords: Depopulation, Sparsely Populated Areas, Rural development policy, Spain

\section{Highlights:}

- Policies addressing depopulation in Spain have had a low impact due to their incorrect diagnosis and design in terms of their contents and governance.

- The objective of these policies should be to enable citizens to reside where they wish and obtain the best possible quality of life.

- A new governance that implies changes in the foundations of these policies and in the way in which they are implemented is essential.

- The strategies developed have to be transversal and demand the joint responsibility of all of the stakeholders. Coordination between different levels of government is vital.

\section{Introduction}

The depopulation of extensive rural areas is a common phenomenon in a large part of the European continent (Marini and Mooney, 2006). Between 1950 and 2007, the European rural population lost around twenty million inhabitants, from $45 \%$ to just $36 \%$ of total population. In the continent as a whole, the rural population decreased between 1950 and 1970 at an average annual rate of $0.3 \%$ and between 1970 and 2000 at $0.2 \%$. The intensity, scope and timing of depopulation in different European countries have varied widely. In Western Europe, between 1860 and 2000, the regions that lost population represented $40 \%$ of France's territory, $29 \%$ of the area of Great Britain, $24 \%$ of Spain and $9 \%$ of Italy. If we analyse only the second half of the twentieth century, the ranking of the regions where the population decreased was led by Portugal where these areas occupied $75 \%$ of its territory, followed by Spain with $54 \%$, Italy with $29 \%$ and Sweden with 18\% (Pinilla et al., 2008). Therefore, like many other European countries, Spain has also experienced an intense rural depopulation process. In 1950, Spain's rural population was a little over thirteen million inhabitants (49\% of the total). However, by the year 2001 it had fallen to 9.4 million (24\% of the total population) (Collantes and Pinilla, 2011).

Economic factors have played a crucial role in depopulation processes. In general, in the European continent, these processes were triggered by high migration rates from rural areas to the urban nuclei. This is known as the rural exodus. The reasons leading so many people to emigrate towards the cities were particularly related to the higher wages, greater job opportunities and better services of the cities resulting from the advancement of the welfare state. There was also a dominant cultural perspective which associated progress and quality of life with the urban way of life (Tomé 2020). Although the particular triggers in each period and in different places and social groups are specific, the decision about where to live is a combination of the efficiency of the market, the cohesion and security of the rights promoted by the institutions, but also, particularly, the personal and family values regarding lifestyle. Prices and wages, laws and taxes, 
together with persuasions and ideals about a specific lifestyle merge and overlap in all social decisions (Anisi, 1992).

The departure of the rural emigrants could have significant effects on the places of origin as it initiates dangerous demographic dynamics. This is because the emigrating populations are predominantly young and the relative ageing of these areas is a significant consequence. Furthermore, this generates low birth rates due to the scarcity of the population of reproductive age. Therefore, the natural growth is negative. This demographic structure can be so unbalanced that even in the medium and long term, when the exit flows weaken or when there are positive migratory balances, real growth can still be negative ${ }^{3}$.

Depopulation tends to generate spirals that feed back into themselves and complicate the future of the areas affected. Consequently, there is a loss of human capital with the departure of those who have most invested in their education and cannot find any attractive occupations in the local labour market. This reduces the economic dynamism of these areas and weakens the community as a social space. Investment or entrepreneurial decisions are discouraged as a consequence of the low expectations and consumption levels that decrease in line with the reduction in the number of inhabitants. Ultimately, the demographic decline leads to a lower economic dynamism according to conventional indicators. However, territorial differences between rural and urban areas in terms of well-being are usually more nuanced (Camarero, 2019).

The future outlook is even more negative when depopulation affects low density areas with imbalances in terms of age structure, gender and qualifications and which also lack an urban system that articulates their territory. This is the case of a large part of interior Spain. For these declining rural communities, which exist in many European regions, the demographic desertification is a symptom of serious structural problems that can lead to their disappearance in the short term. In other words, communities with a long history behind them and even great future potential will be erased.

The seriousness of the depopulation problem is aggravated by the complexity of managing the policies aimed at curbing these depopulation processes, which are very difficult to design and implement. While it is necessary to design approaches that integrate different levels and areas of government involving strategic thinking, it is also essential to implement them effectively with the commitment of the communities affected.

Within this context, the objective of this study is to analyse the principal characteristics of the policies developed until now in Spain to address depopulation and attempt to explain the reasons for their low effectiveness. We seek to provide evidence of this based on the strategies of the two most advanced regions in this respect, Aragón and Castilla y León and on the first designs of the recently proposed national policy. A second objective, closely related to the first, is to propose an alternative approach which could contribute to defining specific policies that rigorously address the challenge of depopulation.

Our hypothesis is that the low impact of these policies is due to a mistaken diagnosis and design in terms of their content and governance. Therefore, we propose that depopulation policies must not seek to achieve a certain number of inhabitants but should have the objective of enabling citizens to reside where they wish and obtain the best possible quality of life. These policies should be implemented within a new governance framework in which the foundations on which they are based and the ways in which they are implemented are renewed. With the support of the European Union, it could be carried out more efficiently with different countries and regions working as a network and could constitute a reference so that the success in territorial cohesion reduces the populist sentiment in the places that believe that they do not matter (Rodríguez-Pose, 2018).

After this introduction, the article describes the theoretical background and methodology. Then, it analyses the process and causes of depopulation in rural Spain. It goes on to assess the policies developed in Spain in response to depopulation. Then, we will define a series of means that we

\footnotetext{
${ }^{3}$ This is the case of many Spanish regions where, even after the rural exodus had finished, the negative natural growth continued generating significant losses in the population (Pinilla et al., 2008).
} 
consider to be fundamental in depopulation policies. Finally, we will analyse the policy implications that can be derived from our study.

\section{Theoretical background and methodology}

Although it is generally assumed that a decrease in population is a synonym of decline, associating population shrinkage with a situation of crisis, this is not necessarily the case. As observed by Lutz and Gailey (2020), "simply taking a country's current population size as the norm is rather arbitrary, and unending population growth is, by definition, unsustainable. So, at some point, the slowing or ending of population growth is natural to be expected". More than being a question about how many people there should be in a territory, we should reflect on their balanced and sustainable distribution within it, achieving generational, social, ethnic and cultural diversity. But the overriding objective should be that people live where they wish after a process of information gathering and deliberation.

Almost all political positions and mainstream research highlight the negative effects of depopulation. These include the difficulties in accessing markets and public and private services when there is a sparse population. Furthermore, the difficulties to access and disseminate new technologies reduce employment opportunities and generate the exodus of the young and more qualified population segments from these areas or an increase in the tax burden due to the reduction in the bases for local taxes (Feser and Sweenly, 1999). In general, both politicians and academics agree that depopulation generates certain negative externalities in terms of the environment, heritage and particularly growth. The environmental externalities arise from the abandonment of the anthropic natural environment through lack of use (Rodríguez Carreras et al., 2013) and the loss of knowledge on ethnobiological and agricultural diversity (Grau and Aide, 2007). The negative externalities with respect to heritage are generated from a depreciation of assets due to a reduction in demand. Together with the low expectations, this would discourage investment, which in turn, reinforces this depreciation (Mankin and Weil, 1989). Finally, the low population density in depopulated areas reduces their productivity, contrary to what happens in urban agglomerations. This generates slightly lower wages in small towns in sparsely populated areas (Goerlich et al., 2020). Furthermore, the high fixed costs of public services limit their provision in these areas (López Laborda and Salas, 2002). The difficulties in accessing public services and low productivity are serious obstacles for economic growth and the well-being of the population.

However, there are also alternative and complementary perspectives. From a neoclassical economic perspective, we can consider that despite these undeniable negative consequences, emigration and the resulting loss in population and abandonment of the villages would be a spontaneous and efficient market response to the misalignment between resources, business opportunities and marginal productivity of the factors between different locations. Therefore, this would contribute to overall growth and the closure of the gap between less and more developed spaces (Coleman and Rowthorn, 2011).

Even from highly innovative analytical perspectives (degrowth theories), some identify positive effects of depopulation: the decongestion of infrastructures, environmental gains, particularly forestland expansion replacing pastureland and abandoned rainfed crops (Meléndez et al., 2014), a higher capital endowment per employee and citizen and the facilitation of self-sufficiency in strategic industries such as energy and food (Dalen and Henkens, 2011; Coleman and Rowthorn, 2011). The New Economy, based on advanced services, enables relocation to rural areas through teleworking. Thanks to outsourced supply chain on very small levels that do not need economies of agglomeration or scale, many activities could be carried out in small factories and workshops. From a socio-economic perspective, Matanle and Sáez (2019) defend a depopulation dividend where there are more opportunities for carrying out personal and social capacities to achieve development in the sense described by Nussbaum and Sen (1993), a qualitative approach that 
is currently inspiring the new indexes of well-being and development of the OECD ${ }^{4}$ and the European Union ${ }^{5}$.

As a result, the debate on depopulation remains open. We are unable to be conclusive and much less able to establish optimum population figures (Lutz and Galley, 2020). Therefore, it is difficult to provide an unambiguously affirmative response from a theoretical perspective to the question of whether public intervention is necessary to correct the situation of sparsely populated areas. There are arguments in favour and against considering that the migratory and residential dynamics are, in themselves, efficient according to their consequences and causes. Therefore, we believe that a precise, technical solution based on "optimum" amounts of population is unattainable. In our opinion the answer should be found in the inhabitants of these areas themselves. The ideal number of inhabitants of a place is defined by those who want to stay there, after a conscious and deep calculation-based information process (Stockdale et al. 2017). Hence, we could derive some kind of answer as to how to combat depopulation and even whether it is appropriate or not, but not ex ante. Therefore, we would propose a subjective efficiency criterion which, although introduced into Public Economics a long time ago as an analytical basis for assessing public policies (Wiseman, 1990), is still very infrequent in the practical debate, compared to quantitative metrics, particularly from technocratic points of view which are dominant.

In our opinion, a quantifiable objective justification of depopulation is both logically inconsistent and unfeasible. Even though political and economic incentives could seem conclusive, it is always a personal option, highly subjective, to decide where to live (García, 2007). Therefore, the key factor is individual freedom regarding their place of residence and their real possibilities as to whether they can have a good enough life there (Paniagua, 2016). So, we should avoid converting depopulation into an arithmetic problem or social engineering which dominates the public debates. We frequently see optimum demographics in media, but there is no reflection on the reasons behind them or the causes generating the exodus of the population or, the most important, whether it was voluntary. It is not frequent to question the opportunity cost associated to leave or to stay, nor about personal expectations or reputation associated to living in these places. We can conclude that we need to redefine the objectives of the local development policies that address depopulation. Their aim cannot be to achieve or maintain a certain number of inhabitants in a rural area, but to facilitate its citizens in residing where they wish, based on autonomous decision making.

With this theoretical approach, we have addressed our research with a methodology largely focused on the assessment of the policies that have been implemented from the point of view of political economy and regional development theories. In the analysis of the territorial dynamics, we have considered that the institutions and intangible factors such as social capital, human capital, innovation or relational capital have a central role. This assessment required a previous analysis of the demographic trends of rural Spain and a study of all of the policies carried out and their elaboration process. The theoretical perspective adopted and the current discussion on rural policies has led us to propose certain lines that should direct the implementation of policies against depopulation. From an applied economics perspective, we conclude with a proposal of public interventions based on the most recent theoretical debate and the most successful experiences in remote rural areas.

\section{Rural depopulation in Spain}

From the final decades of the nineteenth century, significant migration flows left Spain heading towards the American continent, increasing the so-called European transatlantic migration (Sánchez-Alonso, 2000). Also, after 1920, rural areas saw a significant outflow of their population towards urban areas in Spain (Silvestre, 2005). In spite of this, until 1950, the rural population grew because the excess of births over deaths outweighed migration to the cities or abroad.

\footnotetext{
${ }^{4}$ Better Life Index: http://www.oecdbetterlifeindex.org (consulted on 14 October 2020)

${ }^{5}$ European Social Progress Index: https://ec.europa.eu/regional_policy/en/information/maps/social_progress (consulted on 14 October 2020).
} 
The depopulation of rural Spain occurred mainly between 1950 and 1991 as a result of an intensification of out-migration, which clearly outweighed natural growth (Silvestre, 2002). Moreover, as the period progressed, the effects of out-migration on the age structure of rural communities eroded natural growth and eventually led to an excess of deaths over births. The depopulation continued by way of a feedback mechanism. All of this took place with some important regional and local variations (table 1, map 1). The interior regions suffered the most extreme process of depopulation, while the Mediterranean region was an exception to the rule and even experienced some rural population growth (Collantes and Pinilla, 2011).

Since 1991, the Spanish rural population has experienced alternating periods of contraction and growth. The explanation for the exceptionality of the years 2000-2008, in which the rural population grew at a high annual rate, is exclusively due to a significant flow of new residents arriving from the cities and, much more importantly, from abroad. This inflow was much higher than the negative natural change (Collantes et al., 2014).

Two of the regions that have experienced the most intense processes of rural depopulation are Aragon and Castilla-Leon, both located in the interior. In the most intense period of depopulation, both of these regions almost doubled the national average rate of rural depopulation in Spain. Their migratory phenomena were precocious and intense due to their proximity to the main Spanish migratory basins (Bilbao and Madrid in Castilla-León and Barcelona and Valencia in Aragón), the low agricultural productivity of a large part of their territories and their high altitude and slope or semi-arid nature. Since 1991, their loss of rural population, except between 2000 and 2008, has far exceeded the Spanish average. This intense depopulation process, in both regions, has given rise to many academic papers analysing the phenomena and early attention from their regional governments to try to implement corrective policies (Pinilla, 1995; Ayuda et al., 2000 and 2003; Baraja, 2003; Collantes and Pinilla, 2004; Pinilla and Sáez, 2009; Rey et al., 2009; Díez and Pardo, 2020; Sampedro and Camarero, 2020).

Tab 1. Rural population change: Spain, agrarian regions, Aragon and Castilla-Leon (cumulative annual growth rate).

\begin{tabular}{|r|r|r|r|r|r|}
\hline & $1900-1950$ & $1950-1991$ & $1991-2000$ & $2000-2008$ & 2008-2016 \\
\hline Spain & 0.3 & -0.8 & -0.1 & 1.3 & -0.2 \\
\hline & & & & & \\
\hline North & 0.2 & -0.6 & -0.8 & -0.1 & -0.5 \\
\hline Interior & 0.3 & -1.3 & -0.3 & 1.3 & -0.3 \\
\hline Mediterranean & 0.1 & -0.4 & 1.0 & 2.9 & 0.2 \\
\hline Andalusia & 0.6 & -0.7 & 0.0 & 0.9 & -0.2 \\
\hline & & & & & \\
\hline Aragon & -0.1 & -1.4 & -0.7 & 1.3 & -0.6 \\
\hline Castilla-Leon & 0.2 & -1.6 & -0.9 & 0.1 & -0.7 \\
\hline
\end{tabular}

Source: Spain and agrarian regions, 1900-1991 (Collantes and Pinilla, 2011; 1991-2016 (Collantes and Pinilla, 2019), Aragon and Castilla-Leon, 1900-2016 (Own calculation based on Collantes and Pinilla, 2011 and Annual population registers from the Spanish Statistical Institute).

Data refer to municipalities that remained rural (fewer than 10,000 inhabitants) (throughout 1900-1991 for the calculation between 1900 and 1991, and municipalities that remained rural (fewer than 10,000 inhabitants) (throughout 1981-2016 for the calculation between 1991 and 2016).

Agarian Regions: North: A Coruña, Asturias, Cantabria, Guipúzcoa, Lugo, Ourense, Pontevedra and Vizcaya; Interior: Álava, Albacete, Ávila, Badajoz, Burgos, Cáceres, Ciudad Real, Cuenca, Guadalajara, Huesca, León, Lleida, Madrid, Navarra, Palencia, La Rioja, Salamanca, Segovia, Soria, Teruel, Toledo, Valladolid, Zamora and Zaragoza; Mediterranean: Alicante, Balearic Islands, Barcelona, Castellón, Girona, Murcia, Tarragona and Valencia; Andalusia: Almería, Cádiz, Córdoba, Granada, Huelva, Jaén, Málaga and Seville. See map in appendix. 


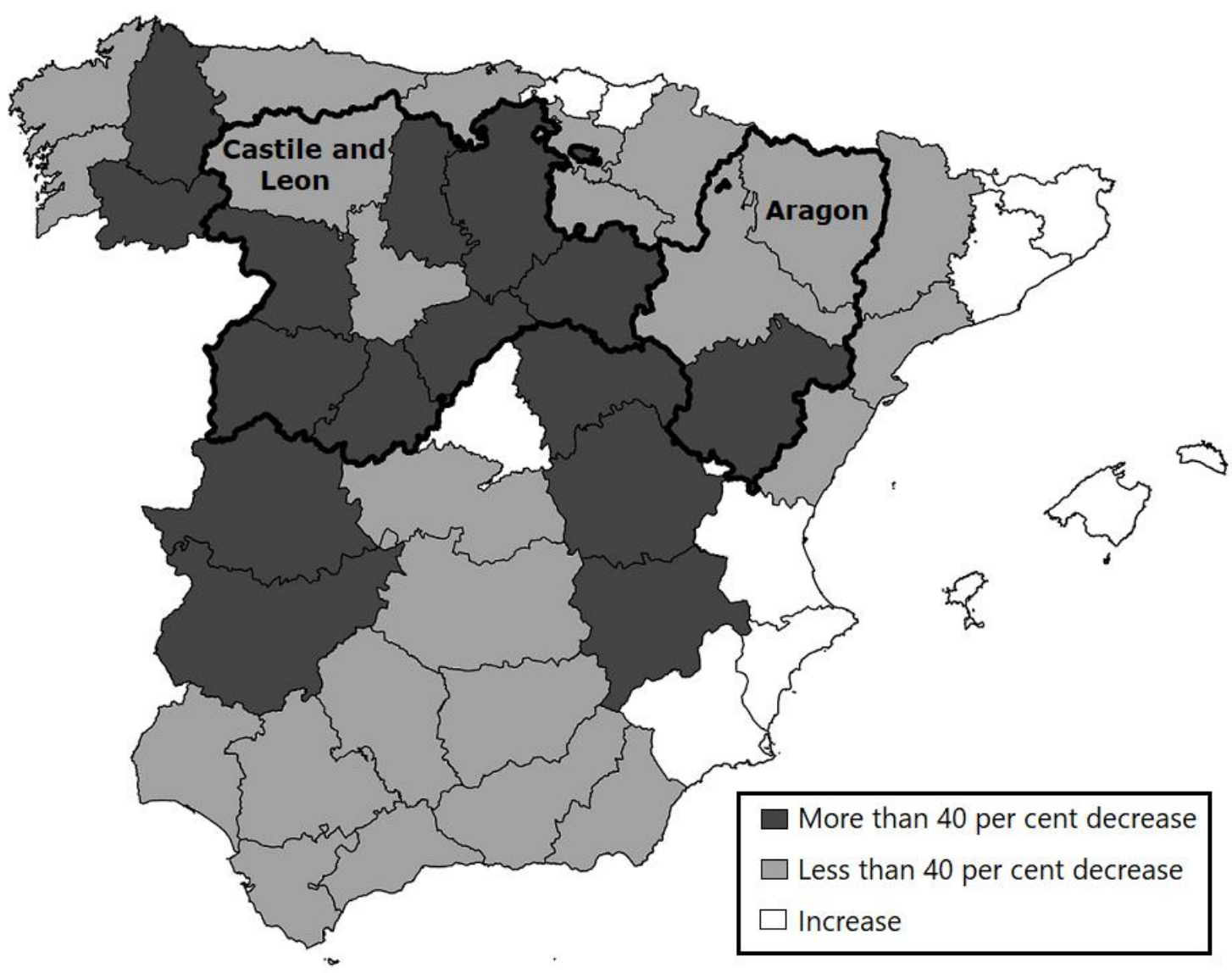

Fig 1. Rural population change between 1950 and 1991. Source: Collantes and Pinilla (2011)

A combination of factors led to the depopulation of rural Spain mainly between 1950 and 1991, largely driven by out-migration from these areas. Agricultural modernisation based on laboursaving innovations and farm restructuring driven by scale economies led to the exodus of a large amount of agricultural population. This population went to look for work in the cities, where primarily industry and services were located, and which in those decades, when the Spanish industrialisation process had been completed, were experiencing explosive growth. In addition, the rural non-farm sector was unable to expand fast enough to prevent depopulation and in urban areas, it was possible to earn higher incomes than in rural areas. The coincidence with the beginning of the construction of the welfare state also generated less access to public services. In short, the combination of a rural penalty in employment and a rural penalty in the access to infrastructures and services created the conditions for massive migration away from the countryside. In addition, the policies prevailing for most of the period, focused on farm restructuring and uninterested in integrated local development, worked in the same direction as these fundamental factors that explain depopulation (Collantes and Pinilla, 2011).

The Spanish rural depopulation process shares similar characteristics with other countries in Western Europe. They have responded to common causes, although with many nuances in the rhythms, periods in which they have occurred or speeds.

\section{Depopulation policies}

\subsection{Changes in territorial management from the 1980s: the prevalence of politics and the omission of cohesion policies}

The death of General Franco in 1975 implied a radical change in the way public policies were managed. There was a transition from a dictatorship and a highly centralised state to a democracy with a high degree of political decentralisation, in fact, one of the highest of the OECD countries (OECD, 2018). It was a long and winding process that started at the beginning of the 1980s when 
the unitary and centralist model became a quasi-federal one, with seventeen regions (Autonomous Communities) bestowed with political capacity in important expenditure functions, some fundamental, such as education, social and health care and practically all of the supplyside policies. In parallel, in 1986, Spain entered the European Community, a club which pursues the convergence of the well-being of its countries and regions through economic integration and a shared powerful cohesion policy. Since then, the regional policy of Spain has gone around these two aspects, territorial decentralisation and European integration, with the central government playing a secondary role until recently.

With respect to regional prominence, the Constitution of 1979 distributed powers and budgets from the central level to the sub-central level in many areas, following a "cooperative federalism" model (Boadway, 1989), used by the majority of western countries, with Germany being a reference for Spain. This model is based on a small hard core of public goods remaining within the scope of the central government with key functions related to equity, stability and economic policy coordination. Some powers have been transferred to supranational bodies such as the European Union, NATO or the ECB. Finally, the central government and the regions share the management of practically all allocative policies and many of those relating to the welfare state, with the central government playing a key role as the coordinator but also as the driver of structural reforms. However, after four decades, the cooperation of different administrative tiers has not been deployed intensely enough with respect to one of their principal targets, that of promoting territorial cohesion (Articles 2, 40 and 138 of the Spanish Constitution). This insufficient vertical (central government with regional and local governments and vice-versa) and horizontal (between the different regional and provincial governments) collaboration has wasted the potentials of a cooperative federal system. The most recent regional and local development approaches reveal the need to combine endogenous and exogenous resources (Bossworth and Atterton, 2012; Gkartzios and Lowe 2019), a strategy that would fit very well with this institutional design. The central government could provide many critical resources that the regions lack together with its relational capital to generate ties between local and global agents and international institutions. Furthermore, promoting the smart and inclusive growth established in the European agenda requires a substantial financial, innovative and technical capacity to manage complex strategies that regional governments would find difficult to obtain on their own.

But in Spain, this new administrative organisation has not led to innovation in agile, efficient and participative forms of public management. Conversely, this has been achieved in other territories with recent devolution process, such as Scotland (Danson and Whittman, 2011), where creative governance constitutes a central element of the fight against depopulation with relative success.

As a result, a regional policy on a national scale for the whole of the country aimed at the cohesion and sustainability of rural territories has, until recently, not existed. Although the Law 45/2007 of 13 December for the Sustainable Development of the Rural Environment was passed, it was only implemented as a pilot project in a few territories and for a very short period of time. Its start-up coincided with the Great Recession and it was never allocated sufficient funds. Therefore, it has rightly been referred to as a "lost opportunity" (González, 2017, Collantes and Pinilla, 2020). Spain has not had a local and regional development policy for the whole of the country which has been sorely needed.

\subsection{The absence of specific policies for rural development}

This lack of action by the central government has had consequences in some areas of its responsibility, in particular, in our case, local development, depopulation and demographic imbalances. These policies have received little regulatory and budgetary support.

Emphasis has been placed on how to implement policies related to education, health, welfare, infrastructures, environmental care, etc. efficiently, equally and with budgetary sustainability as private economic activities do not spontaneously resolve their allocation. That is to say, from a microeconomic perspective, without geographical considerations. However, the challenges of territorial development and cohesion have been neglected. Although evidently, there can be points of intersection between the discourses of Development Theories and those of Fiscal Federalism, the questions posed and the method used to resolve them from the last perspective 
concludes in alternative prescriptions. In other words, from the Public Economics point of view, the objective is not to deliberately promote the factors that determine development or their underlying causes, but to correct market failures through regulation and fiscal policies.

In Spain, although the central government has transferred considerably large amounts of funds to the regional and local governments, the fundamental goal has not been regional convergence or, to an even lesser extent, to address problems such as rural development and depopulation. Rather, there has been a predominance of criteria of overall efficiency and equality related to vertically implemented functions of public spending and the equal provision of basic services forming part of the classic policies of the welfare state and relevant national public goods (mainly infrastructures). The central government has not acknowledged the transversal and holistic nature of the majority of the new social and territorial challenges, which require a strategic, coherent, interdisciplinary and inter-departmental framework of ends and means.

On the other hand, the Spanish Constitution establishes that the regions are responsible for territorial planning, which is vital for addressing the development of shrinking places. However, this planning has generally been applied on a merely technical level (town planning, housing, transport) with an instrumental perspective of management that overlooks contexts and people. Territorial planning has not given rise to hardly any strategic plans with other measures of greater scope. Within these general dynamics of political apathy, it is not surprising that specific plans have only been developed in response to considerable depopulation in two regions, namely Aragón and Castilla y León. A good part of small towns and villages of both of these regions is threatened by serious depopulation problems.

In Aragón, in the year 2000, an Integral Plan for Demographic and Population Policy ${ }^{6}$ was proposed and unanimously passed by its parliament, and it generated great expectations (Ayuda et al., 2003). Its holistic, comprehensive approach was innovative in its day, as it proposed a strategy that was coordinated by different areas of management, yet it avoided becoming, as mentioned in its introduction, an "all-embracing...comprehensive government plan". A risk that, however, has appeared strongly in recent regional and national strategies, a kind of legal encyclopedism. On the other hand, this plan focused on three policies with a distinct territorial and demographic nature and another block related to the central government: family, immigration, territorial cohesion and relevant measures, which were the responsibility of other administrations and for which it proposes a series of lines of collaboration. The strategy was based on the classic means-end framework, although it was innovative with respect to the definition of the goals, expressed in qualitative terms regarding well-being and personal and collective freedom rather than a statistical increase in the population, taking into account the theories and practices debated in the most respected forums. It also explicitly defined the principles and value judgements that inspired the strategy. This is another aspect that is barely present in Spanish legislation but which constitutes a highly useful exercise of transparency for its interpretation and application. It therefore constituted a fairly advanced proposal in terms of its design with respect to the very scarce strategies regarding rural development and policies against depopulation in Spain and even today, it could constitute the object of debate and a source of inspiration (Casini et al., 2021).

Subsequently, one year later, its contents were unanimously completed with different proposals, some aimed at facilitating its implementation, such as an Interdepartmental Commission which would promote its "coordination and follow-up", and an "Institutional Commission of the Aragonese Parliament" which would enable the "analysis of budgets, specific terms in execution and territorialisation in its different areas"7. All of this rich potential in terms of contents and governance, innovative on both a regional and national level in Spain and the stimulus gained from having been unanimously approved, went to waste.

\footnotetext{
${ }^{6}$ Boletín Oficial de las Cortes de Aragón 80, 11 de octubre de 2000.

http://bases.cortesaragon.es/bases/ndocumenVIII.nsf/e86600a24e054a61c12576d2002e551c/b1f5589f70d6dce0c12 57ecb002ef778/\$FILE/PLAN.pdf.

${ }^{7}$ First resolution approved through joint proposals of the socialist party and the Aragonese party parliamentary groups, in the Plenary Session of the Aragonese Parliament of 5 and 6 April 2001, Boletín Oficial delas Cortes de Aragón, $\mathrm{n}^{\circ}$ 121, de 11 April 2001.

https://www.cortesaragon.es/bases/boca2.nsf/(BOCAID)/2B40BAD2CFB41B29C1256A300026049F?OpenDocument
} 
Its implementation was reduced to a few disconnected measures, more for their media impact than their effectiveness, such as the income tax reduction of 600 euros for a third child. The accountability for the integral demographic policy plan was almost non-existent, which has been acknowledged by the very politicians who should have assumed it ${ }^{8}$. Therefore, although this Plan was approved in 2000 , only the lobbying by a minority parliamentary group in 2010 was able to open a brief debate regarding its level of execution, culminating in a vote which did not contemplate examining in greater depth the reasons for its inaction ${ }^{9}$. Therefore, only a few isolated measures have been developed lacking in any kind of strategic planning and failing to comply with all of the procedures required to give them continuity (Palacios et al, 2017).

In 2017, without abolishing or reformulating the previous plan, which indicates the little consideration given to it, a Special Directive for Demographic and Depopulation Policy was passed by the Regional Government of Aragón, again with a holistic-comprehensive approach, which was much more thorough and extensive ${ }^{10}$. After a long process of elaboration, this regulation seemed as though it would become the central pillar of regional government policy from then on.

But, once again, its effective development has been very scarce in terms of the budgetary aspect and its comprehensive management. Therefore, in order to reinforce the items from the expenditure programmes affecting the territory and rural development, the directive contemplates a Territorial Cohesion Fund, which would provide additional support for the projects of companies, institutions and social entities that invigorate the rural environment. However, in the three years of the programme, it was not even convened in one year and its amount was very low, both in absolute terms (€850,000 in 2018; €2,700,000 in 2020) and when compared with other redundant expenditure functions which are much higher.

Neither have those contents and forms of policy-making that would make its holistic and interdisciplinary nature effective been developed. It is true that there is an Observatory of depopulation in which the principal stakeholders take part (lobbies, academic researchers, political and social actors) but only for advisory purposes with no executive capacity. And what we believe to be more decisive is that there is still no efficient interdepartmental coordination with well-organised work teams to address such a complex challenge.

On the contrary, as there is a coalition government and as this initiative is being managed by the Department of Territorial Cohesion by a minority partner of this coalition, the majority partner has initiated proceedings, on its own, to create a new regulation from the Department of the Presidency. The public consultation process of the Bill for Revitalising Rural Areas has just been completed ${ }^{11}$. It is still in draft form, but its initial proposals seek to address depopulation exhaustively and comprehensively, and therefore, it will overlap the strategy that has barely been initiated. It constitutes a clear example of the lack of rigour in the use of the available capacities. It also represents an opportunity to obtain electoral and media benefits, with two political forces competing within the same government. In short, new legislative promises that delay the effective implementation of those already in force, Sisyphus' Aragonese curse.

8 Diario de Sesiones de las Cortes de Aragón 76, fascicle 1, 4 and 5 November 2010. http://bases.cortesaragon.es/bases/ndocumenVIII.nsf/e86600a24e054a61c12576d2002e551c/bea0b24617cbf923c1 2579b500300243/\$FILE/nps277.pdf.

9 Interpellation number 62/10, regarding the general line of action of the Aragonese Government in demographic and population policy carried out by the member of parliament Chesus Bernal, a member of the Parliamentary Group Chunta Aragonesista, Boletín Oficial de las Cortes de Aragón 253. http://bases.cortesaragon.es/bases/original.nsf/(BOCA1)/47A445F58B2393C6C1257797003F0875/\$File/BOCA\%20n um.\%20242.pdf.

${ }^{10}$ Decree 165/2017, of 31 October, of the Government of Aragon, by which the Special Directive of the Spatial Planning of Demographic Policy and that against Depopulation was approved https://www.aragon.es/documents/20127/674325/decreto165_2017.pdf/20f96fe7-0bf2-68cb-9bbc-9701957d3b05 More detailed information about the series of measures that complement it, indicators and studies can be found in the Aragonese Observatory for Demographic and Populational Dynamics http://observatoriopoblacion.aragon.es/.

${ }^{11}$ Consulta Pública previa para elaborar el Proyecto de Ley de Dinamización del Medio Rural https://gobiernoabierto.aragon.es/agoab/participacion/consultas-publicas/96082097500. 
Something similar has occurred in Castilla y León, although at a slower pace and less intensely and with more conventional approaches. In the regional parliament in 2005, its two principal parties, the popular and socialist parties, agreed on a programme document called "Fighting against depopulation. Regional strategy"12, composed of 73 measures. Many of them were merely declarative and others were one-off measures forming a heterogeneous group in which there was no internal coherence or a strategic sense in terms of rural development or territorial cohesion. The objectives were "to establish, integrate and increase the population", that is, merely quantitative goals that mirror those of the Statute of Autonomy, without going into any depth with respect to the possible causes or impacts. To the extent that in its first years in force, until 2009, the flow of foreign immigrants arriving in this region was highly positive, its conclusions were very self-satisfied. They did not observe obvious matters such as the fact that in those rural areas outside of the metropolitan areas, the trends of an ageing population, an imbalance in terms of age and gender and a reduction in the size of the smallest towns, became even worse.

The severe economic crisis beginning in 2008 slowed foreign immigration, changed demographics trends and subsequently, in 2010, the Contents of the Plan were redefined and it was renamed as the "Agenda for the population of Castilla y León"13. Basically, its application has consisted in dressing up as depopulation measures certain actions carried out in the education, employment or business fields with no joint approach to articulate them and without a territorialised approach for the areas suffering from serious decline. Furthermore, an annual report has been elaborated on the demographic evolution based on mere statistical criteria. It does not analyse causes, consequences or possible strategies to implement. Hence, it has been highly criticised and some have called it a non-existent policy or a failure (Díez and Pardo, 2020). Currently, there is a process underway to define a new demographic policy to replace the failed Agenda for depopulation.

These regional policies encounter significant difficulties for their effective implementation. First, they mature over the long term and the electoral cycles are shorter. Therefore, it is not attractive to bear the cost of designing and implementing them without being able to profit from their possible benefits. Furthermore, they require an interdisciplinary approach in terms of knowledge and interdepartmental participation with comprehensive programmes. Thus, collaboration between different areas of government and administration levels, particularly the local level, is necessary. They also require cooperation between public and private agents. Cooperating, coordinating, overcoming corporatism, and having an appropriate qualified perspective of different issues, are demanding and difficult tasks. And, most decisively, those who lead and manage them must apply their rigorous analytical and empirical knowledge, competence and commitment when implementing them (Sáez et al.; 2016). In other words, these are some of the most difficult policies to apply as they require a change in public values inspiring politics working on depopulation issues. This is the case not only in Spain (Ramió, 2017), but in any field, as indicated in research conducted by the European Union, as these policies require new forms of governance (Dubois and Roto, 2012).

\section{Main lines for defining depopulation policies}

\subsection{A new governance}

Such a complex problem as depopulation requires a different approach to those traditionally taken in Spain by politicians and public administration. The major challenges of the rural periphery are still addressed in a sectoral and unidimensional way with the conviction that more public spending, more jobs and a favourable legislation can correct the demographic decline. Even though all of the above is relevant, the way in which a good life is considered is fundamental for deciding where to live. Therefore, depopulation policies should take a transversal, holistic

\footnotetext{
12 Lucha contra la Despoblación. Estrategia Regional. Acuerdo Grupos Popular y Socialista en las Cortes de Castilla y León.

http://bases.cortesaragon.es/bases/NDocumenVIII.nst/e86600a24e054a61c12576d2002e551c/ed048f0e5427aaf1c1 257ed2002b3ee2/\$FILE/luchadespoblacion.pdf.

${ }^{13}$ Agenda para la población de Castilla y León. https://www.jcyl.es/web/es/agendapoblacion/agenda-poblacion.html.
} 
approach and focus on well-being, perceived subjectively in accordance with contexts and life stage (Dyrting et al., 2020). This change of perspective has been adopted in strategies implemented in some countries in Northern Europe, in the so-called vitality policies (Makkonen and Kahila, 2019), with good results.

Hence, a new form of managing territorial planning and depopulation policies is required. In our opinion this would entail the reformulation of two areas: the principles inspiring policies and the way in which they are put into practice. The difference between the successful strategies, or those that were simply implemented, which could be considered in our case acceptable, and those that remained in political agendas without being applied is more related to procedural and institutional aspects than their contents. Consequently, the elaboration process and style of governance is much more important than the specific policies as rural areas are highly idiosyncratic. Therefore, public participation is crucial. As a result, policies should be designed in accordance with the local conditions (Vaishar et al. 2020). Local community should feel like an essential and active part of the policy design and should be co-responsible for the challenge (Ubels et al., 2019; Makkonen and Kahila, 2020). But success cannot be achieved only with local factors. It is necessary to combine endogenous and exogenous resources (Gkartzios and Lowe, 2019), so that bonding and bridging social capital are essential drivers of rural vibrancy (Wu et al., 2019). And, in doing so, to strengthen their competitiveness with extra-regional knowledge and networking pipelines to achieve a critical mass (Sörvik et al. 2015)

For many, debating the principles and instruments that articulate a strategy and its logical consistency and adaptation to the context may seem like a merely formal discussion but in fact, in our opinion, this constitutes a central element or a starting point for this strategy to be consistent and efficient. It is the best way to overcome the ineffectiveness of depopulation policies, their inapplication.

Therefore, we believe that it is necessary to take a strategic approach with the participation of experts from different scientific disciplines, public managers of all areas of government and stakeholders from different social and territorial areas committed to local development. It is important to create spaces for discussion in order to compare arguments and define measures in an agile and rigorous way. Furthermore, the feasible and consistent proposals must be embodied in budgetary programmes with the corresponding precise legislative initiatives instrumented by public and private agents.

With respect to the contents, we should stress that the basic analytical and practical scale when addressing depopulation is the local level. The region, the most common unit in Spanish territorial debates, or even the province, never becomes empty, and depopulation is not a radical problem as a small town is. It is the small village that could disappear, a place with a collective highly defined identity, and so, it becomes the suitable analyses unit. It is true that all villages are connected to supra-local areas and share universal characteristics prone to equivalent measures, but their context is special and requires specific measures (Vaishar et al. 2020). Of course, we should take into account the general trends defining rurality and that all populations belong to a territorial network (Camarero, 2020). So, the repopulation strategies should be contextual and adapted to the strengths and opportunities of each local community, which, in turn, is integrated into an urban system. In this respect, the rural-urban dualism has to be overcome, as we are dealing with hybrid geographies, communities, and citizens (Camarero and Oliva, 2018).

Another relevant question is not defining fascinating goals which are impossible to achieve, as if we were able to change structural and global trends, because this will not lead to better results. Being aware of the possible options and adapting to them would be the correct approach, that of promoting resilient rural communities (Li et al., 2019; Adam-Hernández and Harteisen, 2020).

In this new governance, as we said before, not only is the design and content relevant but the subsequent phase of its specific management is also fundamental: how and who will carry it out, that is, the capacity and commitment of those involved. Laws and budgets applied must be harmonised and well implemented due to their complexity and interdisciplinary nature. They cannot be mechanical and amorphous as the depopulated areas in which they are implemented, are usually very different from one another and change with historical moments and crises. So, it is important to use rigorous criteria based on merit and suitability to select the officials and 
politicians who are going to lead the depopulation and rural development plans. At the last stage, people who are going to specify strategies and measures in the specific territory, adapting them to reality and solving unexpected questions, are as important, or even more so than those who design the strategy (Ramió, 2017).

This leads us to another radical shift, this time with respect to an underlying question in line with the afore-mentioned subjective efficiency criteria; that of appreciating and acknowledging sparsely populated territories with all of their value, a comprehensive wealth (Arrow et al. 2012). They are usually portrayed as vulnerable communities, victims of inevitable accumulative and polarised dynamics of economic growth and whose only solution resides in public incentives, that is, compensatory measures about conventional economics issues. On the other hand, from our point of view, this is an incorrect diagnosis and a merely palliative therapy. Small communities should be appreciated for their intrinsic attractiveness, as the major challenges faced by citizens in the twenty-first century (environmental, energy, cohesion, participation, diversity, creativity) can be better addressed in rural than metropolitan areas, with more resources available than at any time before. Reinforcing the social, relational, human, cultural, natural, political and financial capital of the areas affected is essential for success. In short, it is necessary to make depopulated and low population density areas, particularly communities, attractive places to live, work and interact because they can become a land of opportunities if we add the talent, commitment and creativity within them (Johnson \& Fannin 2019).

\subsection{The European framework as a reference for a new depopulation policy}

In this panorama in which Spanish regional policy has failed to develop effective strategies for sparsely populated areas, the influence of certain approaches and policies of the European Union on rural development has been very important. In Spain, their Rural Development Programmes, and within them, the Community Led Local Development strategies have been significant milestones.

The European Union has contributed to addressing depopulation and shrinking territories with many studies and debates. It has even outlined certain policies and plans but has not formulated a sufficiently robust specific strategy. The European institutions are currently leading forums and debates that may contribute to an EU policy on these types of territories in the next programming period.

The European Union is regarded highly by many countries in which Europeanism is a synonym for a more efficient, vibrant and open society. Furthermore, with respect to territorial planning, local development and depopulation and new policies, the European Commission could be a reference and stimulus. It could contribute the expertise developed in other European territories affected by shrinking population which have had remarkable results. Furthermore, the problems associated with depopulation constitute challenges for a smart, sustainable and inclusive cohesion policy, not only as a geographic space but also as social and political communities in which to redefine the themes and explore solutions. Both for Europe and for countries such as Spain, opportunities arise for sharing a concern about depopulation, based on a more in-depth idea of development from a capability approach (Nussbaum \& Sen 1993) and a well-being notion according to comprehensive wealth (Arrow et al. 2012), concepts useful to better research and governance on sparsely populated areas. Following these considerations, we think that there are several reasons why the European Union should support these policies, reframing remote rural areas as spaces where the creative capacity of local community can emerge, much more after COVID 19 pandemic (Moralli \& Allegrini, 2020).

First, because it is a common European problem as many countries have sparsely populated areas (Margaras, 2016). Although depopulation is fundamentally a local phenomenon, this does not imply that there should not be an overall context within which to insert the areas with depopulation processes. All of these places, however small they may be, form part of broader dynamics, affected by globalisation and the limits of growth and are inter-dependent. So, if the different European spaces affected by depopulation come together, they could compare diagnoses and responses and promote a learning network to inspire shared, innovative actions that should be contextualised within the territory. 
Second, small towns in remote rural areas constitute exceptional laboratories for experimenting with new policies to address some of the challenges faced by Europe (climate change, energy, demography, globalisation (Commission of the European Community, 2008). Such small rural communities are forced to depend on their own capacity to adapt to uncertainties and dilemmas, primarily sharing talent, participation and local engagement. So, many things, theoretical and empirical, can be learned from their process to become resilient territories, putting in value their territorial capital to fuel antifragile projects (Dezio, 2020). In fact, in Japan and other countries with shrinking rural areas, we can find examples of remote rural towns taking advantage of the opportunities provided by the New Economy and a sense of community (Taima y Asami, 2020; Matanle \& Sáez, 2019). In these environments in crisis, technology, creativity, tolerance and social capital can be combined in a more stimulating way to search for solutions that could form part of the policy debate for a continent that also has a decreasing population which is increasingly diverse and ageing (Escalona et al., 2016).

Finally, European institutions could find a novel and distinct relevant issue untouched by member states policies in which it can assume leadership and renew politics, Consequently, focusing on depopulation would contribute to recovering their prestige among the continent's citizens.

In that way, rural development in shrinking areas could be redefined as a challenge relevant for collective welfare and personal well-being, to inspire dynamics that promote civic engagement, rigorous debate and a long-term vision shared by different mentalities and communities. It would be in line with the analytical and governance alternatives promoted by the European Commission together with the OECD (Widuto, 2016). It would require to work with a broader definition of development that adapts better to qualitative living conditions and subjective expectations of the people, which could be applied to the critical situation of depopulated areas. These areas constitute the best example of the contradictions of development and, at the same time, an opportunity to realize another way of life. They are not considered attractive places for most of the people, despite displaying more than acceptable indicators in terms of income, wealth and employment. Their resources are not always adequately valued but the options to fulfil personal capabilities are high. By force of the circumstances, in low density populations and small towns people are the protagonists of their own lives and of the effective vibrancy of their communities.

\section{Policy implications}

First, we have emphasised that addressing rural shrinking requires an open mind able to combine different academic disciplines and areas of government based on a full knowledge of the facts but within a holistic, comprehensive and interdisciplinary approach. To do this, it is essential that the specific policies implemented contemplate three perspectives or levels: the economic, political and socio-community dimensions. The three levels usually overlap and they should be considered jointly in order to make diagnoses and strategies. So, when considering policies to encourage the attractivity of people, companies and social projects to these places, we must appreciate the three motivational dimensions that correspond with them. They act in an interrelated way and makes people and rural communities hybrid entities very idiosyncratic. Therefore, we would have to apply "rural lenses" or "rural proofing" to all policies and evaluate the causes and impacts on macro, meso and micro, general and sectorial levels. Thus, the strategies have to be transversal and holistic.

Given such complexity, there must be a high consistency and coherence in the areas of government involved and there must be co-responsibility between all of the stakeholders. Therefore, coordination between different levels of government is essential in order for the policies developed to be effective. This coordination, intra and inter-governmental is specially lacking in Spain.

Second, rural development, as a synonym for the re-population and regeneration of sparsely populated areas, is usually addressed through different theoretical narratives that adapt the predominant discourse in the growth economy to its context. In this way, in the 1970s, there were proposals for industrialising the countryside and promoting pluriactivity among its active population. The crisis of the 1970 s, basically of the Fordist model, refocused the attention towards the local level and flexibility, where the entrepreneur should enhance the local resources. From 
the 1980s, endogenous development theories were predominant (such as the LEADER model). The growing importance of the environment also led those territories seeking to regenerate to enhance their natural heritage. They did this through tourism or through claiming recognition for their function of conserving natural public goods and favouring positive externalities for the urban environment. From the end of the twentieth century, the importance of innovation and technology has been introduced into the rural world. These factors have great potential in the development of these new activities and business models that enable small companies to enter the value chain of global businesses. To summarise these types of approach, in recent years, in depopulated territories with incomplete economies with large deficits by many capacities, the need has been recognised to combine local resources with exogenous resources. Global perspectives and new neo-endogenous models are also being contemplated (Bock, 2016).

Encouraging decisively to one of these models as a future pillar of re-population or a specific activity on which the usual political discourse is based (rural tourism, food industry, designation of origin, relocation of large companies, infrastructures that are ahead of their demand, top-down digitalisation) ignores the main variable in the competitiveness of the territories and in the wellbeing of the local communities. This is not a specific productive area but something transversal and essential such as talent and commitment. Therefore, rather than using disproportionate subsidies and tax incentives in an artificial way to introduce a sector that has no roots in the territory or specific strategic factors that make it attractive with a dubious dragging capacity, we should promote a creative, entrepreneurial, inclusive, meritocratic culture that prioritises talent and cooperation on an economic, social and political dimensions. These two are intangible inputs, yet more decisive and necessary, that define a local atmosphere as vibrant and motivate all stakeholders. It enables the community to continually reinvent itself and to reframe sparsely populated areas as opportunity places.

Finally, we defend that the policies implemented have to include the participation of the people who live in the sparsely populated areas, and not just be made for the people. This is coherent with what we saw in the previous section, particularly in relation to favouring bottom-up initiatives. This implies that, on a personal level, roots are fundamental. That is, having a connection with a community as a place in which to live a life. This is one of the most important factors in the decision to remain in a community, return to it or leave it. As we saw earlier, the market with its profits or the governments with their taxes and supply of public services are factors that drive away or attract people and families, but the feeling of belonging is highly important and largely conditions the final decision. As the horizons of the decisions to be made widen, it would be desirable to encourage people living in the territory to learn about it in order to better appreciate it. This has positive effects and few drawbacks.

Until now, the majority of the depopulated territories in Spain highlight their critical situation, the urgent need to be helped through budgets and legislation, demanding support from the rest of society in Spain and Europe. Although the underlying diagnosis is largely correct, with serious weaknesses arising from imbalances inherent in growth and exacerbated by unjustifiable policy gaps, this strategy may not be appropriate for attracting investors and future residents. Emphasising the negative aspects and suffering and ignoring the many economic social, personal, tangible and intangible assets, dissuades those who could move there and discourages those who aspire to stay there. In some advanced countries, there is a relevant number of people prepared to reduce their income in exchange for a better quality of life, emigrating to depopulated areas. With the COVID-19 pandemic, there has been a reconsideration of ways of living and working which also involves questioning where to live. In this new situation, small towns in Spain are also now becoming attractive.

From all of the above, we can deduce certain lessons regarding the strategies carried out in Spain. The content of the specific legislation and its technical consistency are important but more decisive are the qualitative aspects that are often omitted. In our case, we have indicated the importance of well-defined objectives, relativising the demographic quantitative indicators in favour of a full meaning of the idea of rural development and community vibrancy. Its rigorous governance is also decisive, taking into account the specific context/social ecosystem of each rural area and the interdisciplinary nature of the rural challenges. Because the relevant question is not how many people live there. In a digital and global world, thresholds are changing every 
day. The question is whether people are able to live in a remote rural area because they want to live there. A better life in remote rural areas is the objective, how many is the consequence.

Our approaches are normative and suggest future government strategies for Spain. Even though the majority of the measures are novel or have only partially been applied, we believe that they are feasible and rigorous. They are based on applied research verified in relevant academic forums, selected for their evidence. In other cases, they arise from systematising different cases of success and also failure (very important too) in institutions dedicated to rural development. In any event, we are aware of the risks of initiating new strategies and propose that some of these measures are only experimental, initially limiting their scope before applying them on a wider scale. The high level of failure or inaction of the depopulation plans in Spain, as we have described in the article, should make us more prudent so as not to generate frustration and worsen their reputation. Therefore, when implementing new policies, it would be advisable to carry out some kind of laboratory policies beforehand, such as, the LEADER initiative and other programmes of the European Commission relating to social innovation and cohesion implemented at the beginning of the 1990s before being generalised.

We are aware that basing a strategy on the will and desires of people and their homes and families can have its risks. Individual decisions about consumption, production or residence do not necessarily coincide with what would be desirable for society as a whole. The jump from micro to macro is one of the most difficult exercises in Social Science, but also in the real world when generating collective decisions that are coherent in ethical and technical terms. If people live where they want, many rural areas may become deserted. But obliging people to live where they do not want to, or bribing them with subsidies or taxes would never be the solution.

Therefore, broadening the perspectives that reveal the advantages and disadvantages of living in depopulated areas, which are currently biased in a negative sense, seems like an interesting proposal. Based on the freedom to choose and a broader outlook that acknowledges the environmental, social and life advantages, not all of the places in risk of depopulation, but many of them, could be regenerated. This is our theory, which we believe, although with uncertainties, is realistic. Because today, the population thresholds in a digital, globalised and well-communicated world do not need to be high to enjoy a good quality of life. The question is how people look at the rural world, a subjective valuation inspired by the possibility to realize personal capabilities in a vibrant community.

In any case, demographic trends towards demographic stagnation, derived from an ageing population, a lower birth rate and urban concentrations are difficult to modify. However, in Spain there are many laws and government strategies that have been passed by all levels of administration and political parties that refer to increases in population and reversing trends, even in remote rural areas that have been shrinking for decades. In our opinion, establishing impossible goals is not only frustrating but leads us to take bad decisions which can affect the efficiency, equity and sustainability of these communities. On the other hand, believing that passing a law in a parliament converts its contents into reality is another common error.

This does not imply that we should be passive and fail to promote an active strategic cohesion policy. As previously mentioned, well-formulated depopulation policies with a rigorous diagnosis and efficient implementation can be highly useful. They will not be able to increase the number and density of the inhabitants of these territories on their own, but they can contribute to a better life for people who live in remote rural areas. To do this, policies should be interdisciplinary with participative governance and promote a creative and sustainable economy. But the principle of promoting sparsely populated areas as places of opportunity in a sustainable way, providing social, ecological and economic resilience is to change the worldview of society, or part of it. In other words, for some people to positively value a rural life in small communities within which to develop their personal project. A mixture of market, government and values is required. A good rural development policy cannot create this without the collaboration of its protagonists; but it can reinforce it, and this is what we have attempted to explain in this study.

Therefore, we propose a radical shift away from the bleak and protesting stance towards one presenting these territories and their people in a positive light as places of challenges and 
opportunities. It is more than a mere aesthetic issue as the repercussions reach the very heart of the matter, that is, the way in which the territory is valued, which is the most decisive factor.

\section{Acknowledgements}

This study has been partially funded by the Ministry of Science and Innovation of the Spanish Government project PGC2018-095529-B-I00, the Ministry of Economy and Competitivity of the Spanish Government project CSO2017-83603-C2-1-R and by the Department of Science, Innovation and Universities of the Government of Aragon (Research Groups S23_20R and S55_20R).

\section{Academic references}

[1] Adam-Hernández, A. \& Harteisen, U. (2020). A Proposed Framework for Rural ResilienceHow can peripheral village communities in Europe shape change? Ager 28, 7-42. DOI: 10.4422/ager.2019.05.

[2] Anisi, D. (1992). Jerarquía, mercado, valores: una reflexión económica sobre el poder. Madrid: Alianza.

[3] Arrow, K. J., Dasgupta, P., Goulder, L. H., Mumford, K. J. \& Oleson, K. (2012). Sustainability and the measurement of wealth. Environment and Development Economics, 17(3), 317353.

[4] Ayuda, M. I., Sáez, L. A. \& Pinilla, V. (2000). El problema de la despoblación en Aragón: causas, características y perspectivas. Boletín de la Asociación de Demografía Histórica 18(1), 137-173.

[5] Ayuda, M. I., Sáez, L. A. \& Pinilla, V. (2003). La despoblación en Aragón: análisis y políticas. In García, F., ed., La lucha contra la despoblación todavía necesaria: políticas y estrategias sobre la despoblación de las áreas rurales en el siglo XXI (pp. 43-104). Zaragoza: CEDDAR.

[6] Baraja, E. (2003). La despoblación, un fenómeno sociodemográfico todavía vigente en Castilla y León. In García, F., ed., La lucha contra la despoblación todavía necesaria: políticas y estrategias sobre la despoblación de las áreas rurales en el siglo XXI (pp. 105126). Zaragoza: CEDDAR.

[7] Boadway, R., Pestieau, P. \& Wildasin, D. (1989). Tax-transfer policies and the voluntary provision of public goods. Journal of Public Economics 39 (2), 157-176. DOI: 10.1016/00472727(89)90038-8.

[8] Bock, B. B. (2016). Rural marginalisation and the role of social innovation; a turn towards nexogenous development and rural reconnection. Sociologia Ruralis 56(4), 552-573. DOI: $10.1111 /$ soru.12119.

[9] Bosworth, G. \& Atterton, J. (2012). Entrepreneurial in-migration and neoendogenous rural development. Rural Sociology 77(2), 254-279. DOI: 10.1111/j.1549-0831.2012.00079.x.

[10] Camarero, L. (2019). Los patrimonios de la despoblación: La diversidad del vacío. PH: Boletín del Instituto Andaluz del Patrimonio Histórico 27(98), 50-69. DOI: 10.33349/2019.98.4517.

[11] Camarero, L. (2020). Despoblamiento, baja densidad y brecha rural: un recorrido por una España desigual. Panorama Social 31, 47-73.

[12] Camarero, L. \& Oliva, J. (2018). Movilidades, hibridaciones rurales y paisajes sociales. En Movilidades, trayectorias vitales y sostenibilidad rural. In Oliva, J., ed., Movilidades, trayectorias vitales y sostenibilidad rural (pp. 21-33). Pamplona: Universidad Pública de Navarra. 
[13] Casini, L., Boncinelli, F., Gerini, F., Romano, C., Scozzafava, G. \& Contini, C. (2021). Evaluating rural viability and well-being: Evidence from marginal areas in Tuscany. Journal of Rural Studies, 82, 64-75. DOI: 10.1016/j.jrurstud.2021.01.002.

[14] Coleman, D. \& Rowthorn, R. (2011). Who's Afraid of Population Decline? A Critical Examination of Its Consequences. Population and Development Review 37, 217-248. DOI: 10.1111/j.1728-4457.2011.00385.x.

[15] Collantes, F. \& Pinilla, V. (2004). Extreme Depopulation in the Spanish rural mountain areas: a case study in Aragon in the 19th and 20th centuries. Rural History, 15(2), 149-66. DOI: $10.1017 /$ S0956793304001219.

[16] Collantes, F. \& Pinilla, V. (2011). Peaceful Surrender. The Depopulation of Rural Spain in the Twentieth Century. Newcastle upon Tyne: Cambridge Scholars Publishing.

[17] Collantes, F. \& Pinilla, V. (2019) ¿Lugares que no importan? La despoblación de la España rural desde 1900 hasta el presente. Zaragoza: Prensas Universitarias de Zaragoza.

[18] Collantes, F., Pinilla, V., Sáez, L. A. \& Silvestre, J. (2014). Reducing depopulation in rural Spain: the impact of immigration. Population, Space and Place 20(7), 606-621. DOI: $10.1002 / p s p .1797$.

[19] Dalen, H. P. \& Henkens C. J. (2011). Who fears and who welcomes population decline? Demographic Research 25, Art. 13, 437-464. DOI: 10.4054/DemRes.2011.25.13.

[20] Danson, M. \& Whittam, G. (2011). Scotland's Civic Society v. England's Big Society? Diverging roles of the VCS in public service delivery. Social Policy and Society, 10(3), 353363. DOI: $10.1017 / \mathrm{S} 147474641100008 \mathrm{X}$.

[21] Dezio, C. (2020). Restart from resources. Rural heritage as Antifragile Territorial Capital. Journal valori e valutazioni $24,209-217$.

[22] Díez, J. M. \& Pardo, A. (2020). Depopulation, ageing and social policies in Castilla y León. Revista Galega De Economía, 29(2), 1-18. DOI: 10.15304/rge.29.2.6959.

[23] Dyrting, S., Taylor, A. \& Shalley, F. (2020). A life-stage approach for understanding population retention in sparsely populated areas. Journal of Rural Studies 80, 439-451. DOI: 10.1016/j.jrurstud.2020.10.021.

[24] Dubois, A. \& Roto, J. (2012). Making the best of Europe's Sparsely Populated Areas. [Working Paper]. Stockholm: NORDREGIO.

[25] Escalona, A.I, Escolano, S., Sáez, L. A. \& Sánchez-Valverde, B. (2016). The location of creative clusters in non-metropolitan areas: A methodological proposition. Journal of Rural Studies, 45, 112-122. DOI: 10.1016/j.jrurstud.2016.03.007.

[26] Fernández, E. \& Rubiera, F. (2020). Population forecast for small areas: estimates for the parishes of five northwestern Spanish provinces. Revista Galega de Economía, 29(2), 1-14. DOI: 10.15304/rge.29.2.7121.

[27] Feser, E. \& Sweeney, S. (1999). Out-migration, population decline, and regional economic distress. Washington, DC: US Department of Commerce.

[28] García, A. S. (2007). Internalizing Immigration Policy within the Nation-State: The Local Initiative of Aguaviva, Spain [Working Paper 151]. The Center for Comparative Immigration Studies, University of California at San Diego.

[29] Gkartzios, M. \& Lowe, P. (2019). Revisiting Neo-Endogenous Rural Development. In Scott, M., Gallent, N. and Gkartzios, M., eds., The Routledge Companion to Rural Planning (pp. 159-169). New York: Routledge.

[30] Goerlich, F. J., Reig, E., Albert, C. \& Robledo, J. C. (2020). Las áreas urbanas funcionales en España: Economía y calidad de Vida. Bilbao, Fundación BBVA.

[31] González, J. (2017). Desarrollo rural en España: una política de estado inaplazable. Documentación social 185, 103-119. 
[32] Grau, H. R. \& Aide, T. M. (2007). Are rural-urban migration and sustainable development compatible in mountain systems? Mountain Research and Development 27(2), 119-123. DOI: $10.1659 / \mathrm{mrd} .0906$.

[33] Johnson, T. G. \& Fannin, J. M. (2019). A New Conceptual Framework for Rural Cultural Wealth [Reseach Paper,]. Rural Policy Research Institute, lowa City: University of lowa. DOI: 10.13140/RG.2.2.32215.32161.

[34] Li, Y., Westlund, H. \& Liu, Y. (2019). Why some rural areas decline while some others not: An overview of rural evolution in the world. Journal of Rural Studies 68, 135-143. DOI: 10.1016/j.jrurstud.2019.03.003.

[35] López, J. \& Salas, V. (2002). Economía y política de la financiación de servicios públicos en territorios con desigual densidad de demanda. Revista de Economía Aplicada 10, 28, $121-$ 150.

[36] Lutz, W. \& Gailey, N. (2020). Depopulation as a Policy Challenge in the Context of Global Demographic Trends. New York: UNDP.

[37] Makkonen, T. \& Kahila, P. (2020). Vitality policy as a tool for rural development in peripheral Finland. Growth and Change, DOI: 10.1111/grow.12364.

[38] Mankiw, N. G. \& Weil, D. N. (1989). The baby boom, the baby bust, and the housing market. Regional Science and Urban Economics, 19(2), 235-258. DOI: 10.1016/01660462(89)90005-7.

[39] Marini, M. B. \& Mooney, P. H. (2006). Rural economies. In Cloke, P., Marsden, T. \& Mooney, P., eds., Handbook of rural studies (pp. 91-103). London: Sage.

[40] Matanle, P. \& Sáez, L. A. (2019). Searching for a Depopulation Dividend in the 21st Century: Perspectives from Japan, Spain and New Zealand. Journal of the Japanese Institute of Landscape Architecture. 83(1).

[41] Melendez-Pastor, I., Hernández, E. I., Navarro-Pedreño, J. \& Gómez, I. (2014). Socioeconomic factors influencing land cover changes in rural areas: The case of the Sierra de Albarracín (Spain). Applied Geography 52, 34-45. DOI: 10.1016/j.apgeog.2014.04.013.

[42] Moralli, M. \& Allegrini, G. (2020). Crises redefined: towards new spaces for social innovation in inner areas? European Societies, 23(Sup. 1), 5831-5843. DOI: $10.1080 / 14616696.2020 .1841263$.

[43] Nussbaum, M. C. \& Sen, A., eds. (1993). The Quality of Life. Oxford: Clarendon Press.

[44] Palacios, A., Pinilla, V. \& Sáez, L. A. (2017). La despoblación en Aragón, 2000-2016: tendencias, datos y reflexiones para el diseño de políticas [Working Paper]. Zaragoza: Universidad de Zaragoza, Facultad de Economía y Empresa.

[45] Paniagua, Á. (2016). Despoblación, sostenibilidad social y espacio rural. Algunas consideraciones para el debate, Ambienta 116, 58-67.

[46] Pinilla, V. (1995). Crisis, declive y adaptación de las economías de montaña: una interpretación sobre la despoblación en Aragón. In Acín, J. L. \& Pinilla, V., eds., Pueblos abandonados: ¿un mundo perdido? (pp. 55-78). Zaragoza: Rolde de Estudios Aragoneses.

[47] Pinilla, V. \& Sáez, L.A., eds. (2009). Tendencias recientes en la evolución de la población de las comarcas aragonesas: el problema de las comarcas demográficamente regresivas (2000-2007). Zaragoza: CEDDAR.

[48] Pinilla, V., Ayuda, M. I. \& Sáez, L. A. (2008). Rural depopulation and the migration turnaround in Mediterranean Western Europe: a case study of Aragón. Journal of Rural and Community Development. 3(1), 1-22.

[49] Ramió-Matas, C. (2017). La necesidad de diseñar en el futuro unos nuevos valores públicos. GIGAPP Estudios Working Papers, 20-38. 
[50] Rey, A. del, Cebrián, M. \& Ortega, J. A. (2009). Despoblamiento y envejecimiento en Castilla y León durante el siglo XX: análisis a través de la emigración femenina y la pérdida de nacimientos. Ager, 8, 113-149.

[51] Rodríguez-Pose, A. (2018). The revenge of the places that don't matter (and what to do about it). Cambridge Journal of Regions, Economy and Society, 11(1), 189-209. DOI: $10.1093 /$ cjres/rsx024.

[52] Sáez, L. A., Ayuda, M. I. \& Pinilla, V. (2016). Pasividad autonómica y activismo local frente a la despoblación en España: el caso de Aragón analizado desde la Economía Política, Ager $21,11-41$.

[53] Sampedro, R. \& Camarero, L. (2020). Foreign Immigration to Rural Spain: An Exploration of the Precarious Rural Cosmopolitanism in the Post-Crisis Scenario. In Döner, F., Figueiredo, E. \& Rivera, M., eds., Crisis and Postcrisis in Rural Territories. Social Change, Challenges and Opportunities in Southern and Mediterranean Europe (pp. 9-30). Cham: Springer.

[54] Sánchez-Alonso, B. (2014). Those who Left and Those who Stayed Behind: Explaining Emigration from the Regions of Spain, 1880-1914. Journal of Economic History, 60(3), 732757.

[55] Silvestre, J. (2001). Viajes de corta distancia: una visión espacial de las migraciones interiores en España. Revista de Historia Económica 19, 247-283. DOI: 10.1017/S0212610900009125.

[56] Silvestre, J. (2002). Las emigraciones interiores en España durante los siglos XIX y XX: una revisión bibliográfica. Ager, 2, 227-248.

[57] Silvestre, J. (2005). Internal migrations in Spain, 1877-1930. European Review of Economic History 9(2), 233-265. DOI:10.1017/S1361491605001462.

[58] Sörvik, J., Teräs, J., Dubois, A. \& Pertoldi, M. (2019). Smart specialisation in sparsely populated areas: Challenges, opportunities and new openings. Regional Studies, 53(7), 1070-1080. DOI: 10.1080/00343404.2018.1530752.

[59] Stockdale, A., Theunissen, N. \& Haartsen, T. (2018). Staying in a state of flux: A life course perspective on the diverse staying processes of rural young adults. Population, Space and Place 24(8), 21-39. DOI: 10.1002/psp.2139.

[60] Taima, M. \& Asami, Y. (2020). Determinants and policies of native metropolitan young workers' migration toward non-metropolitan areas in Japan. Cities, 102, Art. 102733. DOI: 10.1016/j.cities.2020.102733.

[61] Tomé, P. (2020). Las culturas «tradicionales» ante los procesos de despoblación. Práctica urbanística: Revista mensual de urbanismo, 162.

[62] Ubels, H., Bock, B. \& Haartsen, T. (2019). An evolutionary perspective on experimental local governance arrangements with local governments and residents in Dutch rural areas of depopulation. Environment and Planning C: Politics and Space 37(7), 1277-1295. DOI: $10.1177 / 2399654418820070$.

[63] Vaishar, A., Št’astná, M., Zapletalová, J. \& Nováková, E. (2020). Is the European countryside depopulating? Case study Moravia, Journal of Rural Studies, 80, 567-577. DOI: 10.1016/j.jrurstud.2020.10.044.

[64] Wiseman, J. (1990). Principles of Political Economy. Constitutional Political Economy 1(1), 101-124. DOI: 10.1007/BF02393035.

[65] Wu, B., Liu, L. \& Carter, C. J. (2019). Bridging social capital as a resource for rural revitalisation in China? A survey of community connection of university students with home villages. Journal of Rural Studies in press. DOI: 10.1016/j.jurstud.2019.05.008. 
[66] Barca, F. (2009). An Agenda for a Reformed Cohesion Policy; a place-based approach to meeting European Union challenges and expectations. http://ec.europa.eu/regional_policy/archive/policy/future/pdf/report_barca_v0306.pdf.

[67] Comisión Europea (2007). Cuarto informe sobre la cohesión económica y social. Luxemburgo: Oficina de Publicaciones Oficiales de las Comunidades Europeas. $<$ http://ec.europa.eu/regional_policy/sources/docoffic/official/reports/cohesion4/index_es.ht $\mathrm{m}>$.

[68] Margaras, V. (2016). Sparsely populated and underpopulated areas. European Parliament. http://www.europarl.europa.eu/RegData/etudes/BRIE/2016/586632/EPRS_BRI(2016)5866 32_EN.pdf.

[69] OECD (2018). OECD Regions and Cities at a Glance 2018. Paris: OECD. 


\section{APPENDIX 1. MAP A.1. SPAIN'S AGRARIAN REGIONS}

North

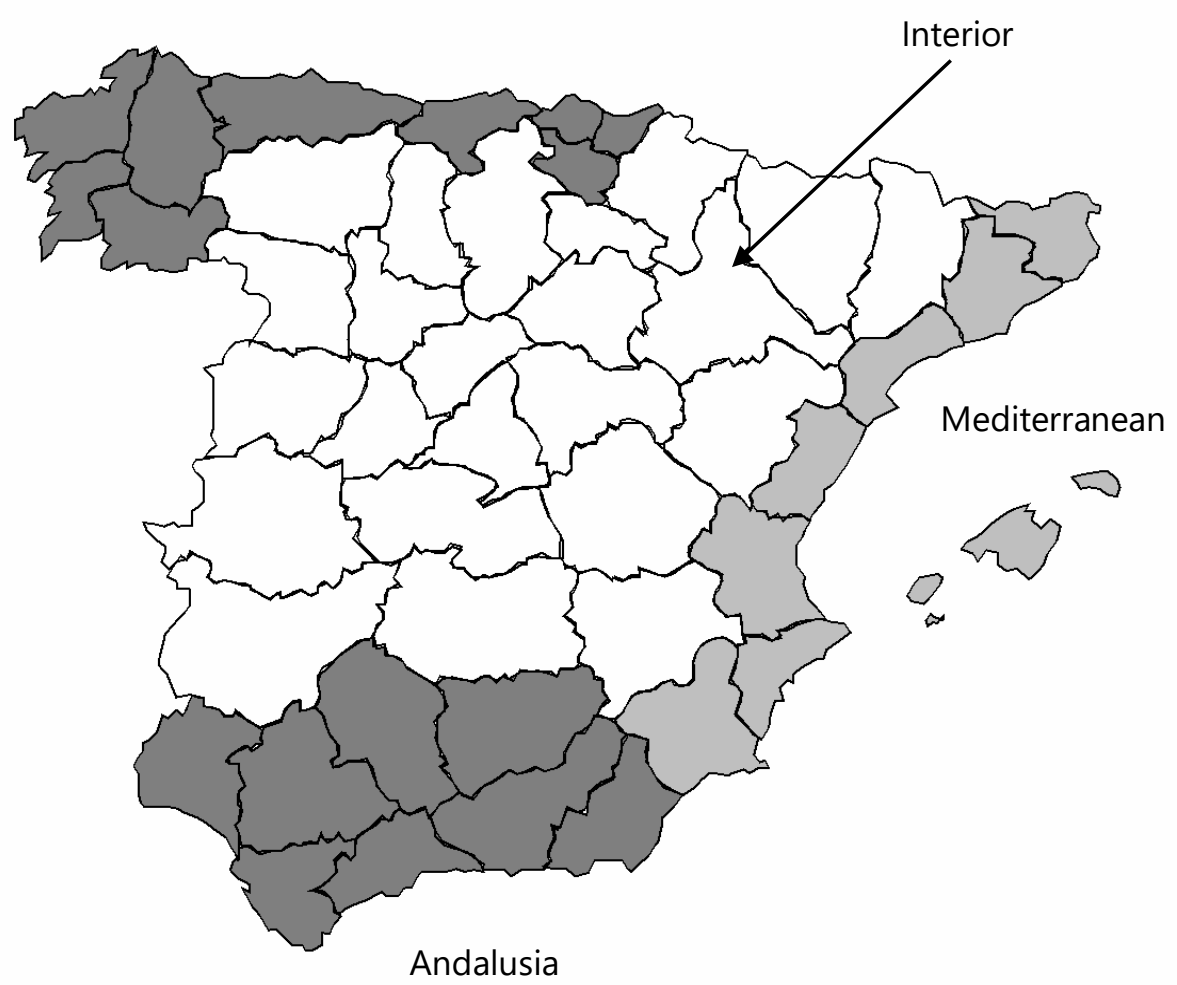

Source: Collantes and Pinilla (2011) 